Michael W. Thomas

\title{
“Other Than They Were": Fair Places Full of Folk
}

\begin{abstract}
Few things are more unpredictable than the convergence of people, landscape and memory. Often, the more time that passes, the more memory has to lean upon imagination to define experiences from the ever-receding past. "The present", notes Ian Jack, "always depends upon the past, which makes the past a necessary subject of any reporter's enquiry" (Jack 2009: xiii). When the reporter is also a poet, however, the enquiry of which Jack speaks assumes a different character, different imperatives. The following essay considers Batmans Hill, South Staffs, 1961-1972, my themed sequence of poems, a return to the human and non-human landscapes of my childhood. One concern of the sequence is how locality defined people and people humanised locality in one region of postwar municipal England. Running alongside that, however, is an awareness of the caprice of memory and a fascination with the ways in which poetry tempers and exploits that caprice.
\end{abstract}

Keywords: England, imagination, landscape, memory, poetry, post-war, working-class.

Came moving before me a marvellous vision;

I was lost in a wild waste; but where, I discerned not.

I beheld in the east, on high, near the sun,

A tower on a hill-top, with turrets well wrought;

A deep dale beneath, and a dungeon therein,

With deep ditches and dark, and dreadful to see.

A fair field, full of folk, I found there between,

Of all manner of men.

-William Langland, The Vision of Piers the Plowman.

When people, landscape and memory meet, the consequences are often unpredictable. Memory is, it would seem, the lynch-pin: that faculty which occupies the border between current and former life, but which so often requires that imagination should supply the deficits of recall. Journalist and social commentator Ian Jack observes that "the present always depends upon the past, which makes the past a necessary subject of any reporter's enquiry" (Jack 2009: xiii). But what happens when attempts are made to convey the past in a themed sequence of poems? How is that dependency managed? What processes are required to strike a balance between the factual recovery and the poetic re-imagining of lost people and places? And what part does landscape play in such attempts?

In Batmans Hill, a themed sequence of poems, I return to certain people and places of my childhood. Distance, differing paths of life and (in some cases) death separate them from me now. Yet, however clearly or imperfectly remembered, they played their parts, decisive or low-level, in shaping how I look back upon the often fragmented, misty reaches of Then.

This exploration, therefore, draws upon key elements from Batmans Hill in an attempt to discover how place defined people and people humanised place in one corner of post-war municipal England - and to determine, as far as possible, how the vagaries of memory and demands of poetry have tempered that discovery. Intrinsic to this attempt is the depiction of 
differing landscapes: individually, in uneasy concert and, sometimes, in clear collision. Unlike Maurice Chevalier, I cannot blithely claim, "Yes, I remember it well". But perhaps, writing the sequence, I found an unlikely ally in capricious recollection. The following poems and reflections will demonstrate how far my aims have been realised.

Batmans Hill, Coseley, South Staffordshire, was an English council estate completed in 1953 and thus a target for all manner of epithets: 'New Elizabethan', for example, in vogue then and giddily revived and be-flagged in 2012. It was the kind of much-ballyhooed project that was covered in Pathe newsreels of the time: postwar housing clearance; blueprints for a starry future; the exodus of families and communities from Victorian or between-wars accommodation to the New Jerusalem (front-lawn laburnums optional). It is easy to imagine film footage of removal vans disgorging their contents in a Batmans Hill crescent while a school-of-Downton voice intones, A great day for the Figgises as they take occupancy of their dream home. Two-bar fires in every room, lavatories upstairs and down, even a servinghatch to make Mum's life easier when she's dishing up the tea for her young Elizabethans. Hurry up, Grandma-you don't want to be the last to drool over the Gas Board cooker!

Here, we encounter a familiar dichotomy of perspectives. The Pathe approach, freighted with the need to emphasise the upbeat, would obviously dwell on the shiny and new. Its approach was necessarily part of a larger project to present Britain as well and truly recovering from the depredations of 1939-45 and thus, in the current, desolating phrase, 'open for business'. It contributes to the officially-sanctioned narrative. Alongside it, however, another narrative tells itself, as it always has and will: the realities of people's lives, the everyday triumphs and reversals (sometimes occupying the same minute) that create the textures of their experience and make them who they are right up to any given point. In Batmans Hill, I focus on the latter narrative while acknowledging, albeit implicitly, that the former-progress, the construction of a new communal living-space to which a particular group of people is transplanted-weaves in and out of the writing. I am mindful that the landscapes of the poems are often the result of the negotiation between officially-constructed spaces and the idiosyncrasies of the behaviour that occurs within them.

Reading, drafting, re-reading (and occasionally despairing of) the poems in the sequence, I also discovered that a number of sub-landscapes were in play. These helped to define the people on whom I focused and fix them in my mind-allowing, of course, for the undependable agency of memory. More, I was reminded of the different challenges faced by prose and poetic memoirists. Prose memoirs are challenging enough (to read, in some cases, as much as to write). A prose memoirist might decide to play fast and loose with, say, a sequence of remembered events, placing this one here even though it happened there, in the interests of dramatic effect, of reader engagement. However, they are still working with the most immediately accessible form of communication: prose narrative, with its implicit promise of sequence, of delineated cause and effect. This is not to say that prose memoir is an easy genre in which to work. Indeed, prose memoirists, like their fiction counterparts, might decide that it best serves their purpose to subvert development and sequence throughout an entire work, cutting and splicing them Citizen Kane-style. But poetry, with its compactness, its fondness for allusion and intimation - at times, its disregard for any sense of development-can intensify the challenges that the memoirist faces.

Batmans Hill covers particular recollections from 1961 to 1972: in pop-cultural terms, the period from when the Beatles were riding to the rescue over a distant horizon to when Benny Hill was offering his mock-elegy for Ernie, The Fastest Milkman In The West. The poems I have selected for discussion include portraits of individuals, meditations on specific places and co-existent landscapes. In the poem that follows, I also unearthed conflict, realising that it did not arise solely from the mismatch between nation-centred and localised narratives: 


\title{
In Lilac Time
}

1963

Go down to Kew in lilac time, in lilac time, in lilac time

Go down to Kew in lilac time (it isn't far from London)

Alfred Noyes, The Barrel-Organ

\begin{abstract}
All I remember are small rooms the shin-level gas of dissension

the kitchen chirped once, at Christmas

a red breast beat life through the transom-pane
\end{abstract}

come Boxing Day the snow was ash

the pantry-mouse flattened its back against another year

on telly people called Askey and Ray

staggered after comedy's clean heels

at school we sang Rule Britannia

glowed from it all over playtime like Windscale mistakes

the skin of Assembly visitors

sang Castile melodies

clicked into line

like the sides of an overnight coffin,

voices bittered on early fog, snot a-tumble,

we went down to Kew in lilac time

in lilac time

mom's law came sideways: a maid-of-all-work

flaring a grate inside my face

dad's was the small kid's gambit

a bonny bunch deep in the spine.

At last I shut the gate

housefronts folded behind my steps

at the crescent's end I died, lived, broke off a billow of lilac. 
Three landscapes are in play here: those of home, school and nationhood, the last conveyed by the elegant tub-thumpery of Noyes' poem (a staple choice for class recitations in junior school back then). The home landscape is developed through allusions to household places: 'small rooms', 'the transom-pane', and the mouse-haunted pantry. It finds its tone through intimations of domestic argument ('dissension') and the pre-packaged fodder beamed in by Broadcasting House and Granada ('Askey and Ray' - about whom all this writer can say is, thank God for Hancock and Steptoe). A 'New Elizabethan' element moves the poem from home to school, with its communal rituals, its status as the first step towards socialisation and matters civic. We did indeed sing 'Rule Britannia', even though we were unaware that, in imperial terms, the shop was being rapidly dismantled around us. And the school setting offers what is arguably the clearest sub-landscape: the classroom recitation, rehearsed and performed for visitors of various provenance-school inspectors or benefactors with Humber Super Snipes parked outside. In retrospect, the scene suggests below-stairs staff dutifully trooping into the Hall to do their Christmas turn for 'Maister an' Mis'ress.'

As for the landscape of nationhood, its representative is a now rather fey Edwardian lyric. There is (possibly) some sardonic humour in the meeting of one world, Kew Gardens and all it invokes, with the world inhabited by a fidgety bunch of Junior 2 children in the decidedly un-Kew-like Black Country. My feeling was that this collision gave a sharper edge to that previously dramatized in the poem, between home and school. (It should be stressed, however, that such feelings may only emerge after re-working a poem. Writing first or early drafts can sometimes feel like tentative encounters with Sanskrit.)

The locations of the sequence are not restricted to Batmans Hill and its surroundings. The next poem moves into another world altogether, suggesting greater opportunities for contradictions and collision. However, placed as it is, near the end of the sequence, it derives much of its effect from the prior establishment of Black Country places and perspectives:

\section{Upper Ballyroe, Kilfinnane}

1968, the Uncle's farm

We stand and watch the rain.

The sloping field

strikes loose its waters

rides them down

to pools of mahogany gumbo.

The hayricks are what's left

when mountains unbuckle their splendours

fall by fall. Their crowns cave and suck.

Chemistry happens. The rotten stem

swaddles the firm.

One of us is leant against a tree, swelling its black scars

with crooked breath, head stuck

in last night's fuddle.

His free hand wags at his hip, a cigarette strung on its fingers. 
Someone forecasts: brighter than scrubbed beans

come teatime. Then we'll get on.

Fecksakes, the cig flares back at him,

it's torrents now, well into the boozing hour

and down to the heel of tomorrow besides.

We'll see the summer out forking blancmange, and where were the bloody tarps?

The tarps are asleep, interfolded like sofa cats

in the barn we walked past hours ago,

swatting off the sun ...

... which someone else swears he's glimpsed,

just, way and gone over the field:

a finger of it laid underside

the gapping wounds of cloud.

Ah, he insists, it'll turn for us now.

But it has business

with cliffs and trawling-roads.

It slithers off (Fecksakes)--another kind of cat, squeezing up space for itself

under the sag of a dresser,

or with the last of retreat up its tail

as a window unratchets and slams.

This poem could be taken as a moment of pastoral in the sequence, a breather from the corporation lamp-posts, the menace of No Ball Games Here signs. It records an incident from what was almost an annual event: the summer holiday on an uncle's farm in County Limerick. It also symbolises some of the challenges of memoir-writing highlighted at the start of this exploration: principally, the attempt to balance factual recovery with the poetic re-imagining of lost people and places. The essential incident is true enough. Often more capricious than its English counterpart, the Irish weather beat down a field of carefully-built hayricks. Some exchanges, familiar blends of banter and pugnacity, did ensue about whether the sun would return and the day could be at least partly saved. The rest, however, is invention underwritten by a general experience of how my Irish family would behave in adversity and how the fields of the Republic would look when sodden. Perhaps, as with the other poems in the sequence, Upper Ballyroe supports the observation of French writer, Patrick Lagrange, as quoted by a character in Julian Barnes' The Sense of An Ending: "History is that certainty produced at the point where the imperfections of memory meet the inadequacies of documentation" (Barnes 2011: 17). After all, imperfect memory and inadequate documentation are meat and drink to the poet: the chip-board doors through which imagination can break and enter.

Whatever the poem has to offer, however, landscape plays the central part. Difference of landscape is presented through the fact that this is emphatically not where the sequence's 
speaker spends most of his time. In that context, the visit to the Uncle's farm would stand comparison with the crew of USS Enterprise breaching an unknown spiral arm. The poem, therefore, echoes the disconnection between Kew Gardens and the post-war school recital-fest in In Lilac Time. To the young observer, the 'mahogany gumbo' of the rain-soaked fields, the way the collapsing ricks 'cave and suck,' the 'gapping wounds of cloud' overhead appear strange, even fantastic. Hayricks, after all, are in short supply in the environs of God's Little Acre and The Celestial City, as Wolverhampton and Birmingham were popularly and respectively known. (It is worth noting here that a similar mordant humour informed the nicknames for other West Midlands localities. 'The Lost City' was an area of particularly dense housing beyond Princes End; while a beguiling mix of the salacious and the Biblical dubbed an adjacent district 'Sodom.' Comparable nicknames are used in other post-industrial regions, suggesting the same blend of defiance and self-deprecation.)

The sense of near-exotic difference applies also to the language 'quoted' in the poem. Here, admittedly, I have had to employ the David Copperfield manoeuvre, in which my younger sensibilities, such as they were, have been modified and put in their best suit by my older, more reflective self. I'd love to claim that the farmhand's retort to the notion that the sun will return-

Fecksakes $[\ldots]$

it's torrents now, well into the boozing hour and down to the heel of tomorrow besides.

We'll see the summer out forking blancmange, and where were the bloody tarps?-

was recalled verbatim. Instead, I have been obliged to create a response that draws upon a lifetime's exposure to the rhythms and inventiveness of Irish-English (for example, 'at the heel of the hunt' for the deadly dull 'at the end of the day'; and 'between the hopping and the trotting' for 'what with one thing and another'). As for Fecksakes, this would appear to be a linguistic imperative now enforceable by EU law.

Batmans Hill, however, is not all group portraits in parti-coloured spaces. Some of the poems focus upon individuals and where they stand in my memories of those formative years: a blood-and-thunder parish priest; a young girl who died long before her time; and Raymond Earl, subject of the poem below. Focusing on these people, I found that they trailed specific landscapes in their wake: or, rather, that those landscapes constructed themselves silently around them, like the edges of a developing photograph. Indeed, in Raymond Earl, the eponymous character's image and behaviour call forth landscapes both overt and implicit:

\section{Raymond Earl}

\section{9}

Raymond Earl didn't have a single doorknob in all his head

took a Shut sign to the world save when it fed and pillowed him

or dug about for a joke he might rattle to, a face he might hail through his deepwater light 
but give him a ball and he could vapourize

the spleen of Hannibal. Thigh to foot

he drove without a car

wore down a realm of sixpences

with brake and spin. Up close, skidding, despairing of a tackle,

you heard him prove the nothingness of words

bump noise far to the back of his throat

show that language only worked

when poured south to the engine muscles

then he was gone, leaving you

in your man-trap of turf

with a ghost on your right foot

re-tingling the jump of the ball.

He had a trial for Wolves.

Didn't fancy. Early mornings. No chips.

Last time I saw him was in the wounded hollows

of the district park

hup-hupping a World Cup '66 ball-

Bobby Moore's name, Nobby's, Geoff's and Jack's

hanging like suns the sky was made for petitioning the hem of an archangel's gown

with mud and genius

I should say here that I've altered his name. The chances are that he won't read thisbut he was a big lad: why risk it? A much admired lad, too: as the poem tries to show, he spoke to the world largely through his footballing skill. He wasn't much good with words and concepts: was seen as on the dense side. But by whose valuation? That of a society which, at the time, was even more infected than it is now by a sense of hierarchy, social confidence and eloquence at the top, slowness tending the horses down below? In one crucial respect, Raymond Earl was not slow. In fact, to reverse a comment above, it could be said that words and concepts weren't much good for him: a perspective enforced by the real and implied landscapes that emerge in the poem.

The definable landscape is one part-admired, part-mocked by Paul Whitehouse in the character of Ron Manager from BBC TV's The Fast Show: "Summer evenings. Kick-abouts in the park. Jumpers for goalposts. Marvellous, eh? Marvellous". Shadowing it, howevereven supplanting it in much of the poem-is the interior landscape I imagine Raymond to inhabit: the world of the genius, with Wembley, Munich, Rio de Janeiro contributing its 
hinterlands. The poem seeks to define the kind of language such a landscape requiresinstead of intelligible words, the noises of intent, concentration, triumph. Raymond did indeed make such noises, as though he were charting the progress of his play like World Cup '66 broadcaster Kenneth Wolstenholme with a scarf where his mike should be. His footwork, then, did prove "the nothingness of words", save as pockets of an energy which was quite properly "poured south to the engine muscles".

This interior landscape, however, never made itself real for him. In the end, he was perhaps too firmly rooted in Batmans Hill to capitalise on the successful trial he had for Wolverhampton Wanderers. The landscape of Ron Manager's goofy reverie emerges in full at the end of the poem: "the wounded hollows/of the district park", exhausted from bike-tracks, fights, games of football and cricket in their seasons. Here, too, overt and implicit landscapes meet, like spectators watching Raymond's solitary practice. Where he actually was in his head, I couldn't presume to say. The end of the poem, however, offers a convergence between a definable place and a landscape of glittering possibility, symbolised by the "World Cup '66 ball—/ Bobby Moore's name, Nobby's, Geoff's and Jack's". The effect could variously be called poignant, wistful, a piece of suburban stoicism. Or, in Raymond's world, nothing to do with language at all — just another outing for wondrous talent with a scuffed, beloved ball.

The above speculation suggests that, in Batmans Hill, characters and their places are indeed rendered as other than they actually were. This has little to do with deliberate falsification, but rather with the way that memory and imagination must work in concert to bridge the gaps that the years hollow out - and, in the interest of poetry, to make what is or is not clearly remembered as vivid and absorbing as possible. (And, whatever fond fancies the writer might entertain on that score, the verdict always rests with the reader.) Landscapesdefinable or covert, as clear as paving-stones or shimmering about an action, a phrase, a conversation - play a crucial part in the endless negotiation between factual recovery and the play of the imagination. Often, of course, they do so by helpfully lingering longer: a memoirist might remember the geography of a pub or street-end long after the particulars of debates held there-Wolves' chances (with or without Raymond Earl), the likelihood of World War III, why the new 10cc album isn't a patch on the last-have faded away.

Other than they really were. Perhaps, in the end, that phrase is not completely accurate. Such, at least, is my hope in regard to Batmans Hill. In it, I have also sought to recover what might be called essences - of people, place, event - even if the way they looked, sounded, felt has required imaginative transfusion. Creative rendering of the past and its landscapes is, in equal measure, a tricky and beguiling business. Laura Marcus notes, "Much contemporary interest in autobiography [. . .] is in the interrelation between theory and experience, the interplay of different voices, and the representation of the past as a complex and elusive terrain" (Marcus 1994: 278). That last word. Never far from excursions into memory, prior selves, the "fair fields of folk" who populate the stages of life. Terrain. Country. Landscape.

\section{References:}

Barnes, Julian. 2011. The Sense Of An Ending. London: Cape. Jack, Ian. 2009. The Country Formerly Known As Great Britain. London: Vintage. Marcus, Laura. 1994. Auto/biographical discourses. Manchester: Manchester University Press.

Thomas, Michael W. 2014. Batmans Hill, South Staffs: 1961-1972. London: Flipped Eye. 
Thomas Michael W.“Other Than They Were”: Fair Places Full of Folk, Crossroads. A Journal of English Studies 2013/1, 86-93. 